range, and depends only on the rudder angle and not on the speed. At high speeds, therefore, the turning advance is smaller than the stopping advance; as speeds falls, the two become identical, and at low speed stopping advance is the shorter of the two. (This takes no account of the tendency of the ship to behave irrationally when the rudder is hard over and the propellers reversing. Occasionally under these conditions ships make sharp turns, often to starboard, either because of the unbalancing effect of the righthanded screw propeller, or, in Dr Tani's opinion, because the course stability of the ship becomes extremely poor.)

What conclusions can the captain draw from these unexpectedly complicated considerations ? At high speed, a full rudder turn is probably the best course, without reversing the engines. At lower speed, reversing the engines and putting the helm hard over may be best. If the object to be avoided is approachingas, for example, in a collision situation-the important criterion is to reduce speed in as short a time as possible; in this case, although the ship may be travelling above the critical speed, a crash-back procedure with engines in reverse is recommended.

\section{Saturn Aloft}

\section{from a Correspondent}

LAST week's first Saturn V flight (called Apollo 4) may have helped NASA to catch up on the lagging timetable for landing two Americans on the Moon by 1970. By combining in one flight the first operational tests of several important components, time has been saved and many of the tactical obstacles to the first manned flight in the Apollo capsule cleared away. That flight is now fixed for autumn 1968, employing the less powerful Saturn I as booster for a low Earth orbit to check the capsule under "live" conditions. At least three further steps of graduated difficulty must follow before the lunar landing attempt.

There is no doubt of the technological achievement of the first Saturn V flight, however misplaced or outdated may now seem the goal of a manned Moon landing by 1970. The organization and co-ordination by themselves compare with an important military exercise-with far less margin for improvization. That the launching took place to the minute- -0700 hours local time, October 8--marks the planning efficiency and the soundness of the new Moonport Complex 39 at its first launching.

The chief engineering tasks to be met were these. The unflown first stage (F 1), presumed the biggest booster ever to take off, used conventional fuel, but to concentrate a thrust building up to 8.5 million pounds within 150 seconds depended on the fine adjustment and balance of the supply of 28,000 pounds-per-second of propellant for simultaneous burning in five matched engines. The second stage, delivering one million pounds, had never flown before and used tricky liquid hydrogen as propellant in its five clustered $(J-2)$ engines. To ensure smooth transfer of power between stages, eight solid fuel rockets used for stage separation also had to "settle" the super-cooled liquids in the bottom of their tanks to ensure instant feed under high vacuum and weightlessness. The thind stage centred on a single liquid hydrogen $J-2$ engine, with fourteen other rockets for ancillary purposes. The critical and pre- viously untried test for this stage was to restart the main engine after two Earth orbits to push the vehicle out to a distance $(9,300$ nautical miles) whence it could start a simulated lunar return and re-entry to prove the Apollo capsule's heat shield. This involved accelerating it downward by means of further rocket burns and high precision onboard control only partly prompted from the ground to ensure correct attitude, angle and so on, to narrow margins for the high speed collision with the atmosphere. A glancing blow, $7.13^{\circ}$ (to local horizontal), on the heat protected blunt forward end of the spacecraft was called for, and achieved.

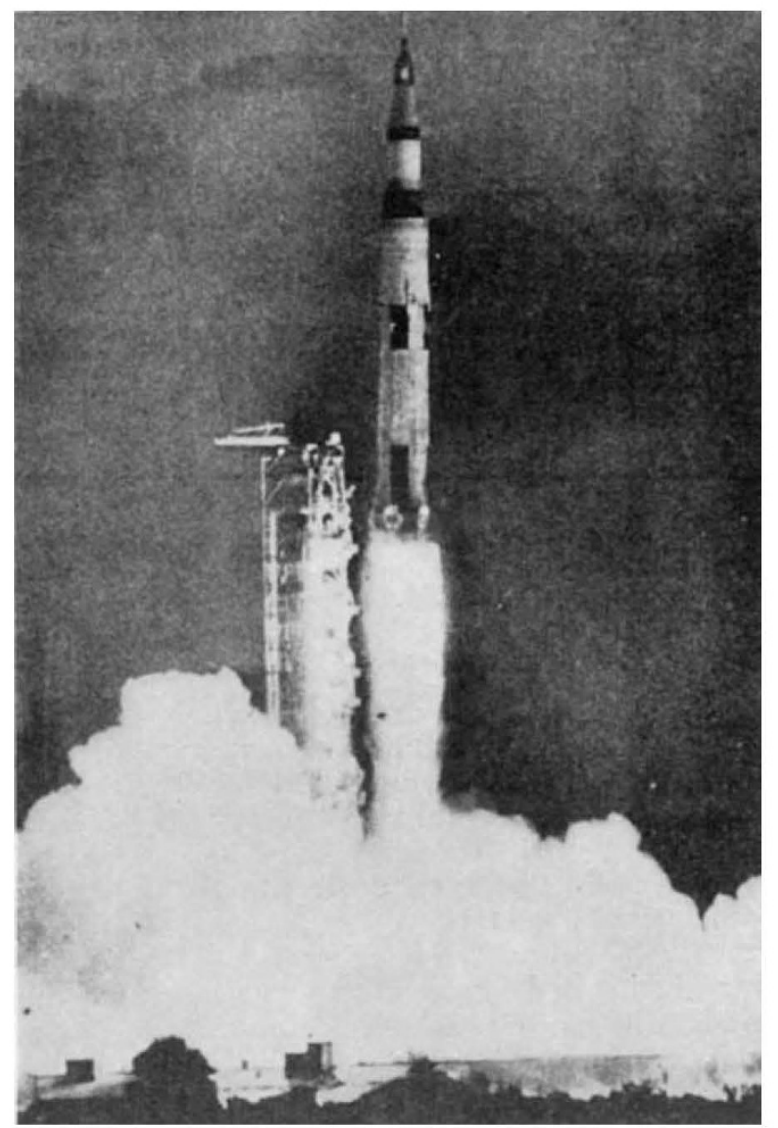

\section{More Action on Aldabra}

Convincen that Aldabra Atoll should be preserved entire without the air staging post which the Ministry of Defence wants, the Royal Society has made a further approach to the Secretary of State for Defence. Since its last approach in May, the society has reappraised the case in the light of the results of the preliminary ecological survey of the atoll and of recent modifications to the defence proposals. These proposals would limit any development, if and when a decision is taken, to the eastern end of the south island, instead of involving all the islands of the atoll as originally planned.

The Royal Society has repeated that any development on Aldabra will upset the integral ecosystem, which is the great scientific interest of this, the last remaining ecosystem of its kind in the Indian Ocean. Confining the air staging post to one part of one island will not save the ecosystem. It would not be possible 
to put effective barriers between parts of the atoll, and in any case the eastern area of the south island is the most interesting part of Aldabra. Once development begins, the destruction of the ecosystem, which has been occurring very slowly ever since domestic animals and weeds were introduced by the settlers who arrived in 1888, will be accelerated, and the ecosystem as it is now-largely unaffected by manwill eventually be destroyed. In its new approach the Royal Society has stressed the great value of Aldabra as an integrated island ecosystem the study of which would give information valuable not only to biological science but also for the understanding of other ecosystems, including those of economic and social importance.

\section{New Post}

Following the discovery of natural gas, the Gas Council announced, in its annual report earlier this year, a reorientation of its research policy into two sectors, one to cover current problems and the other to investigate the full and economic use of natural gas. The council is now advertising for a distinguished scientist to direct all research activities, which means taking charge of the five research establishments and an annual expenditure of at least $£ 2.5$ million. The post is a new one and remuneration is a matter for discussion, but corresponding research posts in the National Coal Board and the Central Electricity Generating Board command salaries in the $£ 7,000$ to $£ 9,500$ range.

\section{Safe Vaccine}

A NEW method for preparing canine distemperhepatitis vaccine in established cell lines of canine kidney tissue has been developed by Dr L. Brown, director of the biological research division of Norden Laboratories Inc., Lincoln, Nebraska. Dr Brown described the method at a conference for the Division of Biologies Standards at the National Institute of Health, Bethesda, on November 6-8. The vaccinecontaining two attenuated live vaccines and called 'Enduracell D-H', has been used to vaccinate approximately one million dogs since it was first introduced in 1963.

There are several advantages in using an established cell line for vaccine production. A cell line of this nature contains only one kind of cell and every cell is genetically related: each cell therefore has the same biochemical characters, the same growth rate, the same virus susceptibility and, when infected with a virus, will respond in the same way. As a result, vaccine production is very regular; it contains a uniform virus concentration and has consistent antigenic potency. It is important to use cells for vaccine production from the same species in which the vaccine will be used. This ensures that the virus maintains its maximum ability to invade cells of a given species, resulting in maximum immunity. It also reduces the danger of foreign protein reactions.

The DK line is produced from a master seed stock and every serial of vaccine is produced at the same passage level. This development of uniformly potent and safe vaccine is to be extended to the production of rabies vaccine for dogs, cats and cattle, and Dr Brown. anticipates that it will soon be possible to prepare all vaccines in established cell lines.

\section{Parliament in Britain}

\section{Oceanography}

DR J. BRAY, Joint Parliamentary Secretary, Ministry of Technology, said that research was proceeding with the hope of increasing the range of optical detection in turbid water, and the National Research Development Corporation, in conjunction with the Ministry of Defence, had patented and was exploiting a non-optical imaging system for underwater viewing. The corporation had for some months been studying with a group of industrialists the requirements of a technologically based diving activity, and this group was now engaged in generating the necessary development work to produce a wide range of aids and equipment for submarine use. In common with the governments of other member countries of the United Nations, the Government was cooperating in a comprehensive survey of activities in marine science and technology, with a view to formulating proposals for an expanded programme of international cooperation in oceanography. (Written answer, November 7.)

\section{Biological Warfare}

The Minister of Defence for Equipment, Mr R. Mason, said that the Government's policy was to publish as much as possible of the results of microbiological research at the Porton Laboratory. Last year forty papers by the staff of the Microbiological Research Establishment were published and members of the staff gave lectures and attended national and international symposia. An annual report, in the form of abstracts of all original work published, was issued to about 300 libraries at universities, research institutions and industrial organizations, and copies were available on request. From December 1, 1967, all suitable unclassified departmental reports would be released to the National Lending Library for Science and Technology. Much of the work was helping the medical research centres. (Oral answer, November 8.) Weather

Mr. M. REes, Under-Secretary of State for Defence for the Royal Air Force, stated that over the next four years the British contribution to the World Weather Watch was expected to amount to some $£ 2 \cdot 5-£ 3$ million, or about 7 per cent of the total cost. Britain had offered to act as a Regional Meteorological Centre and a Regional Telecommunications Hub, to continue to develop its research effort, to improve surface and upper air observations and to provide free training for overseas meteorologists. In addition, he said, Britain would make substantial amounts of equipment available for use for developing countries and would make an additional annual contribution of $£ 30,000$ to the World Metcorological Organization. (Written answer, November 8.)

\section{Student Grants}

Mrs Shirley Williams, for the Department of Education and Science, said that grants to students in the current academic year would cost an estimated $£ 129$ million. $£ 9$ million of this was for postgraduate awards and the remainder for first degree courses. Mr Patrick Gordon Walker said the raising of the school leaving age to 16 in 1971-2 would cost $£ 44$ million in the first year. It was too soon to tell, he said in answer to another question, whether the $£ 0.5$ million set aside for aid to overseas students would prove adequate. (Written answer, November 9.) 